Матеріали Всеукраїнської науково-практичної конференчії «Актуальні питання діагностики, лікування, раціональної фармакотерапії, диспансеризації та реабілітації в практичі сімейного лікаря"

DOI

\title{
ДИНАМІКА ПОКАЗНИКІВ ВУГЛЕВОДНОГО ОБМІНУ У ПРОЦЕСІ КОНСЕРВАТИВНОГО ЛІКУВАННЯ ДИФУЗНОГО ТОКСИЧНОГО ЗОБА
}

๑О. 3. Ліщук, Г. І. Суслик, Б. Ф. Ліщук

Львівський національний медичний університет імені Данила Галицького

Актуальність проблеми. Дифузний токсичний зоб (ДТЗ) - органоспецифічне автоімунне захворювання, при якому тиреоїдостимулювальні антитіла (АТ-рТТГ) впливають на рецептори тиреотропного гормону гіпофіза, що призводить до підвищення синтезу тиреоїдних гормонів і дифузного збільшення щитоподібної залози. В останнє десятиріччя з'явилась велика кількість робіт, присвячених проблемі порушень вуглеводного обміну при ДТЗ. Як виявилось, тиреоїдні гормони не лише регулюють диференціювання, ріст і метаболізм майже всіх клітин організму людини, але й причетні до різних аспектів обміну глюкози та інсулінової відповіді.

Мета. З'ясувати закономірності змін показників вуглеводного обміну у хворих на дифузний токсичний 306 до та після лікування тиреостатичними препаратами.

Матеріал та методи дослідження. У дослідження включили 23 хворих на ДТЗ, середній вік яких становив 43,4 року, з них 19 жінок і 4 чоловіки. Пацієнтів відбирали під час амбулаторного прийому у Львівському обласному ендокринологічному центрі, а також після консультацій на кафедрі ендокринології Львівського національного медичного університету. Рандомізовані для дослідження хворі не мали значущої супутньої патології і не отримували жодного лікування з приводу ураження щитоподібної залози. Тривалість дослідження становила $(180 \pm 12)$ діб. Усі пацієнти отримували тиреостатичну терапію тирозолом у дозі, яка під- биралась індивідуально і коливалась в межах від 5 до 30 мг на добу. До і після курсу кожного етапу терапії у пацієнтів визначали рівень тиреотропного гормону гіпофіза, вільного тироксину та вільного трийодтироніну, антитіл до пероксидази, антитіл до рецепторів тиреотропного гормону та до тиреоглобуліну, оцінювали концентрацію глюкози, інсуліну та С-пептиду натще, вміст глікозильованого гемоглобіну, обчислювали індекс інсулінорезистентності HOMA-IR. Статистичну обробку даних проводили варіаційно-статистичним методом. Вiрогідність відмінностей оцінювали за t-критерієм (критерій Стьюдента). Різницю параметрів вважали статистично значущою за $\mathrm{p}<0,05$.

Результати дослідження. Після шести місяців лікування тирозолом спостерігали нормалізацію показників тиреоїдної панелі. Було отримано достовірне підвищення рівня інсуліну від $(8,7 \pm 0,43)$ мМО/л до $(12,71 \pm 0,62)$ мМО/л та С-пептиду від $(1,84 \pm 0,11)$ до $(2,4 \pm 0,12)$ нг/мл. Відмічено тенденцію до зростання глікозильованого гемоглобіну від $(4,76 \pm 0,08)$ до $(5,02 \pm 0,11) \%$. Індекс HOMA-IR збільшився до значень $(2,77 \pm 0,47)$ у порівнянні з вихідними показниками - $(1,97 \pm 0,16)$.

Висновок. Отримані дані підвищення вмісту глікозильованого гемоглобіну, інсуліну та C-пептиду натще, індексу HOMA-IR у порівнянні з даними показниками до початку проведення тиреостатичної терапії підтверджують наявність порушення вуглеводного обміну у хворих на дифузний токсичний зоб. 